\title{
Proximate Content, Phenol and Mineral Fertilizer Effects on Infection and Weight Loss in Dioscorea Rotundata (Three Varieties) and D. Alata) (One Variety) Incubated with Botryodiplodia Theobromae
}

\author{
Otusanya MO* \\ Department of Crop protection, College of Plant Science and Crop production, Federal University of Agriculture Abeokuta, Nigeria
}

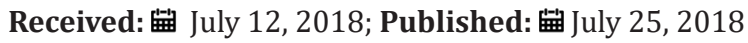

*Corresponding author: Otusanya MO, Department of Crop protection, College of Plant Science and Crop production, Federal University of Agriculture Abeokuta, Nigeria

\begin{abstract}
Resistance to tuber rot by Botryodiplodia theobromae in relation to tuber phenol and proximate content was investigated in this study in variety Agbodo of Dioscorea alata and varieties Oniyere, Iseosi and Abuja of $D$. rotundata. The four varieties harvested from a field plot where they had been fertilized with an 8-mineral content fertilizer (Bounty), were incubated with B. theobromae for 4 weeks along with their counterpart (the same four varieties) sourced from farmers' plots. The experiment was a $4 \times 3$ factorial, with 4 main factor treatments (variety), 3 subfactor treatments of $0.6 \mathrm{ml} \mathrm{l}^{-1}$ and $1.2 \mathrm{ml} \mathrm{l}^{-1}$ Bounty fertilizer, and farmers' plot tuber (FPT). There were 3 replications. Only the fertilized tubers were analyzed for phenol and mineral content in a 4 by 2 factorial experiment, as resistance to tuber infection by $B$. theobromae had correlated significantly with phenol and mineral uptake in white guinea yam (unpublished). Mineral fertilizer effects in infection (2.27\%) and weight loss (2.11\%) was evident as both were $97 \%$ lower and $67 \%$ lower respectively than those recorded for two improved Dioscorea varieties fertilized with calcium carbonate in literature. However, $0.36 \%$ (infection) $/ 0.49 \%$ (weight loss) of FPT tubers were significantly lower than those of the fertilized tubers. Lower moisture and higher phenol content in Oniyere did not reflect in lower weight loss or infection than the other varieties. Analysis of tuber phytochemicals including phenol/phenolic compounds generally as well as minerals in the tuber which are all implicated in infection reduction should explain varietal response.
\end{abstract}

\section{Introduction}

Yam Dioscorea species is a staple food in the tropics and humid regions of the world. Major production is in West Africa and Nigeria had been the world's largest producer for several decades. The importance of yam is exhibited in it being a food security and income generating crops, as well as one with components useful for pharmaceuticals. Yams also display a variety of uses socially and in ethnic religion in many areas of the world such as West Africa where some species are Indigenous, such as the guinea yams ( $D$. rotundala Poir and D. cayenensis Lamk.) Dioscorea alata, water or greater yam is popular along with the white and yellow guinea yams in Nigeria. Higher levels of protein as well as various Vitamins and minerals make yams more nourishing than cassava - the poor man's food. Production is more labour intensive than for cassava and constraints therein makes it lag demand both locally and in international foreign markets. Major losses in stored tubers are caused mainly by fungi [1] such as Aperpillus species, Penicillium species, Botryodiplodia theobromae, Rhizopus nodulans and $R$. stolonifer among others. These annually losses in millions of metric tons weight was estimated at 7 million [2]. Minerals nutrition for disease resistance remain relatively cost effective than chemical control with attendant-environmental/health hazards [3]. This study investigated the response of 3 common white guinea yam varieties and 1 water yam variety in South West Nigeria to infection after mineral fertilization, compared to these same varieties sourced from farmer's plots. The objective of the study was:

a) To determine phenol and proximate content in bountyfertilized $D$. rotundata vars Oniyere, Iseosi and Abuja and D. alata var. Agbodo, after incubation with Botryodiplodia theobromae for 3 weeks.

b) To relate phenol content and moisture in the fertilized tubers to infection and weight loss, after incubation with Botryodiplodia theobromae.

\section{Materials and Methods}

\section{Source of Tubers}

One set of tubers of the three varieties Oniyere, Iseosi and Abuja of Dioscorea rotundata and var. agbodo of D. Alata were sourced from a yam project plot at the Teaching and Research Farms of DUFARMS (Directorate of University Farms), Federal University of 
Agriculture, Abeokuta, Ogun State, Nigeria. The tubers had been fertilized in the yam project plot with bounty fertilizer containing eight minerals namely Calcium $7 \% \mathrm{w} / \mathrm{w}$, Magnesium oxide $0.50 \%$ $\mathrm{w} / \mathrm{w}$, manganese $1 \% \mathrm{w} / \mathrm{w}$, Iron $2 \% \mathrm{w} / \mathrm{w}$, Zinc $2 \% \mathrm{w} / \mathrm{w}$, Copper $0.50 \% \mathrm{w} / \mathrm{w}$, Boron $0.0025 \% \mathrm{w} / \mathrm{w}$, and Nitrogen $15 \% \mathrm{w} / \mathrm{w}$. Rate of fertilization was $0.60 \mathrm{ml} \mathrm{l}^{-1}$ and $1.20 \mathrm{ml} \mathrm{l}^{-1}$ of Bounty fertilizer. Another set of the four varieties were sourced from farmers plots within Ogun State (South West region of Nigeria).

\section{Infection and Weight Loss Determination After Inoculation and Incubation with Botryodiplodia Theobromae}

A 4 by 3 factorial experiment was carried out arranged in RCBD (randomized complete block design) with 3 replicates. Main plot factor was variety (four) and the 3 subplot factors were fertilizer namely $0.60 \mathrm{ml} \mathrm{l}^{-1}$ bounty fertilizer, $1.20 \mathrm{ml} \mathrm{l}^{-1}$ bounty fertilizer and no bounty or farmers plot tuber (FPT). Tubers were inoculated with a $5 \mathrm{~mm}$ agar disc of a 7-day old pure culture of Botryodiplodia theobromae. The $5 \mathrm{~mm}$ discs of $B$. theobromae were introduced into the surface sterilized tubers with sterilized scalpel, forceps and $5 \mathrm{~mm}$ cork borers; after $10-12 \mathrm{~mm}$ deep holes had been made in the tubers with sterilized $6 \mathrm{~mm}$ cork borers. The inoculation site of each tuber was sealed with pure petroleum jelly after the cut-out tissue had been inserted into the hole. Arrangement of inoculated tubers was in ventilated, wire-netted wooden yam storage structures inside the COLPLANT (College of Plant Science and Crop Production), Federal University of Agriculture (FUNAAB) screenhouse for 3 weeks. Tubers were weighted before inoculation with a top loading mettler balance. After 3 weeks, weights of the tubers were again recorded. The infection site on each tuber was cut open after the Vaseline was cleared with spatula and cotton wool, with a steel knife. Infected tissue was carefully removed with a sharp scalpel on to pre-weighted aluminum foil. Infected tissue weight was determined with an electronic balance.

Weight loss was determined using the formula \% Weight loss $(Y)=((A-B) / A) 100$, Where $A$ and $B$ are weight of tuber before inoculation and at the end of the experiment respectively. Infection was determined using the formula \% Infection $=(C / A) 100$, Where $C$ $=$ corrected weight of infected tissue.

And $C=100 X /(100-Y),[4]$.

Where $\mathrm{X}=$ weight of infected tissue and $\mathrm{Y}=\%$ Weight loss.

And $\mathrm{A}=$ Weight of tuber before inoculation.

Data Analysis

Percent data were transformed appropriately before analysis of variance. Means were separated using Tukey's Studentized range (HSD) test.

\section{Results}

Infection and Weight Loss in Two Species of Dioscorea (Four Varieties) From a Bounty-Fertilized Yam Project Plot and From Farmers Plots After 3 Week Incubation with Botryodiplodia Theobromae
The range of infection in the four varieties was $1.028 \%$ to $2.119 \%$ with no significant difference (Table 1). Range of infection in the subfactor means, that is fertilizer rate including farmer's plot, was $0.364 \%$ to $2.714 \%$. The farmers plot tubers had significantly lower infection of $0.364 \%$, than the $0.60 \mathrm{ml} \mathrm{l}^{-1}$ and $1.20 \mathrm{ml} \mathrm{l}^{-1}$ Bounty-fertilized tubers which had $1.817 \%$ and $2.714 \%$ respectively (Table 1). Interaction of variety x fertilizer, or variety $x$ FPT (farmers' plot) had no significant differences in infection as shown in table 1 . Varietal weight loss range in the 3 weeks was $1.37 \%$ to $1.94 \%$ with no significant differences (Table 1 ). Tubers from farmers; plot however had lower weight loss of $0.49 \%$ than the $1.20 \mathrm{ml} \mathrm{l}^{-1}$ and $0.60 \mathrm{ml} \mathrm{l}^{-1}$ bounty-fertilized tubers which had $2.11 \%$ and $2.10 \%$ respectively. The bounty-fertilized tubers were not significantly different from one another in weight loss. Interaction of Agbodo x FPT (farmers plot) was $0 \%$ for weight loss. It was significantly different (lower) than the bounty-fertilized tubers of Abuja which had 2.48\% (Abuja x $1.20 \mathrm{ml} \mathrm{l}^{-1}$ and 2.51\% (Abuja x $0.60 \mathrm{ml} \mathrm{l}^{-1}$ ) weight loss. The bounty fertilized tubers of Abuja also had significantly higher weight loss than Oniyere x FPT which had $0.32 \%$ weight loss. The seven remaining interactions (weight loss of $0.32 \%$ to $2.06 \%$ ) were not significantly different from Agbodo x FPT as shown in (Table 1).

Table 1: Infection and weight loss in two Dioscorea spp. (four varieties) from a Bounty-fertilized yam plot and from farmers' plots after 3 weeks incubation with Botryodiplodia theobromae.

\begin{tabular}{|c|c|c|}
\hline Variety & $\%$ infection & $\%$ weight loss \\
\hline Isesoi (D. rotundata) & $2.119 a$ & $1.40 \mathrm{a}$ \\
\hline Oniyere $(D$. rotundata $)$ & $1.844 \mathrm{a}$ & $1.57 \mathrm{a}$ \\
\hline Abuja (D. rotundata) & $1.536 a$ & $1.94 \mathrm{a}$ \\
\hline Agbodo (D. alata) & $1.028 \mathrm{a}$ & $1.37 \mathrm{a}$ \\
\hline \multicolumn{3}{|c|}{ Fertilizer (Bounty) } \\
\hline $\mathrm{F} 1\left(0.60 \mathrm{ml} \mathrm{l}^{-1}\right)$ & $1.817 \mathrm{a}$ & $2.10 \mathrm{a}$ \\
\hline $\mathrm{F} 2\left(1.20 \mathrm{ml} \mathrm{l}^{-1}\right)$ & $2.714 \mathrm{a}$ & $2.11 \mathrm{a}$ \\
\hline FPT (Farmers' Plot) & $0.364 b$ & $0.49 \mathrm{~b}$ \\
\hline \multicolumn{3}{|c|}{ Interaction } \\
\hline Iseosi X F1 $\left(0.60 \mathrm{ml} \mathrm{l}^{-1}\right)$ & $2.893 a$ & $1.71 \mathrm{abc}$ \\
\hline Iseosi X F2 $\left(1.20 \mathrm{ml} \mathrm{l}^{-1}\right)$ & $3.163 a$ & 1.67abc \\
\hline Iseosi X FPT (farmers' plot) & $0.300 \mathrm{a}$ & $0.82 \mathrm{abc}$ \\
\hline oniyere X F1 $\left(0.60 \mathrm{ml} \mathrm{l}^{-1}\right)$ & $1.753 \mathrm{a}$ & $2.20 \mathrm{ab}$ \\
\hline Oniyere X F2 $\left(1.20 \mathrm{ml} \mathrm{l}^{-1}\right)$ & $3.497 a$ & $2.20 \mathrm{ab}$ \\
\hline Oniyere X FPT (farmers' plot) & $0.283 a$ & $0.32 \mathrm{ab}$ \\
\hline Abuja X F1 $\left(0.60 \mathrm{ml} \mathrm{l}^{-1}\right)$ & $1.260 \mathrm{a}$ & $2.51 \mathrm{a}$ \\
\hline Abuja X F2 $\left(1.20 \mathrm{ml} \mathrm{l}^{-1}\right)$ & $2.997 a$ & $2.48 \mathrm{a}$ \\
\hline AbujaX FPT (farmers' plot) & $0.350 \mathrm{a}$ & $0.82 \mathrm{abc}$ \\
\hline Agbodo X F1 $\left(0.60 \mathrm{ml} \mathrm{l}^{-1}\right)$ & $1.360 \mathrm{a}$ & $2.06 \mathrm{abc}$ \\
\hline Agbodo X F2 (1.20 $\left.\mathrm{ml} \mathrm{l}^{-1}\right)$ & $1.200 \mathrm{a}$ & $2.06 \mathrm{abc}$ \\
\hline Agbodo X FPT (farmers' plot) & $0.523 a$ & $0.00 \mathrm{c}$ \\
\hline
\end{tabular}

Means in any column followed by a common letter are not significantly different at $\mathrm{P}=0.05$ (Tukey's test). 


\section{Proximate and Phenol Content Analysis}

Table 2: Proximate content (\% dry matter) and Phenol (mg/100g dry matter) in two Dioscorea Species (four varieties) from a bountyfertilized Yam plot after 3 week incubation with Botryodiplodia theobromae.

\begin{tabular}{|c|c|c|c|c|c|c|c|c|}
\hline Yam variety & Moisture & Dry matter & Fat & Ash & Crude fiber & Crude protein & Carbohydrate & Phenol \\
\hline ABUJA (AB) & $13.90 \mathrm{a}$ & $86.10 \mathrm{~b}$ & $0.55 b$ & $2.78 \mathrm{a}$ & $8.75 a$ & $4.16 \mathrm{~b}$ & $83.80 \mathrm{ab}$ & $135.26 b$ \\
\hline AGBODO (AA) & $13.59 a$ & $86.41 b$ & $0.62 \mathrm{ab}$ & $2.73 \mathrm{a}$ & $8.80 \mathrm{a}$ & $4.04 \mathrm{~b}$ & $83.84 a$ & $133.87 b$ \\
\hline ISEOSI (IS) & $12.78 \mathrm{a}$ & $87.22 b$ & $0.63 a$ & $2.72 \mathrm{a}$ & $8.61 \mathrm{a}$ & $4.05 \mathrm{~b}$ & $84.09 \mathrm{a}$ & $122.89 b$ \\
\hline $\begin{array}{l}\text { ONIYERE } \\
(\mathrm{ON})\end{array}$ & $8.38 \mathrm{~b}$ & $91.70 \mathrm{a}$ & $0.59 \mathrm{ab}$ & $2.73 \mathrm{a}$ & $9.04 a$ & $4.92 \mathrm{a}$ & $83.38 \mathrm{~b}$ & $163.55 a$ \\
\hline \multicolumn{9}{|c|}{ Bounty Fertilizer $\left(\mathrm{ml} \mathrm{l}^{-1}\right)$} \\
\hline 1.2 & $12.76 a$ & $87.25 a$ & $0.60 \mathrm{a}$ & $2.75 \mathrm{a}$ & $8.73 a$ & $4.20 \mathrm{a}$ & $83.73 a$ & $138.83 a$ \\
\hline 0.6 & $11.58 \mathrm{a}$ & $88.43 a$ & $0.59 \mathrm{a}$ & $2.72 \mathrm{a}$ & $9.16 a$ & $4.38 \mathrm{a}$ & 83.83a & $142.45 a$ \\
\hline \multicolumn{9}{|c|}{ Interaction } \\
\hline AB X 1.20 & $15.16 \mathrm{a}$ & $84.85 c$ & $0.57 \mathrm{a}$ & $2.81 \mathrm{a}$ & $9.07 \mathrm{~b}$ & $3.82 \mathrm{~d}$ & $83.73 a$ & $126.99 \mathrm{~cd}$ \\
\hline $\mathrm{AB} \times 0.60$ & $12.65 \mathrm{ab}$ & $87.35 b c$ & $0.53 a$ & $2.75 \mathrm{ab}$ & $8.46 \mathrm{~d}$ & $4.49 \mathrm{bc}$ & $83.87 \mathrm{ab}$ & $143.52 \mathrm{bc}$ \\
\hline AG X 1.20 & $14.23 \mathrm{ab}$ & $85.77 \mathrm{bc}$ & $0.61 \mathrm{a}$ & $2.73 \mathrm{ab}$ & $8.82 \mathrm{bc}$ & $4.00 \mathrm{~d}$ & 83.86ab & $132.00 \mathrm{bcd}$ \\
\hline AG X 0.60 & $12.96 \mathrm{ab}$ & $87.05 b c$ & $0.63 a$ & $2.74 \mathrm{ab}$ & $8.75 b c d$ & $4.09 \mathrm{~cd}$ & $83.81 \mathrm{ab}$ & $139.46 \mathrm{bc}$ \\
\hline IS X 1.20 & $13.42 \mathrm{ab}$ & $86.58 \mathrm{bc}$ & $0.62 a$ & $2.72 \mathrm{ab}$ & $8.60 \mathrm{~cd}$ & $3.98 \mathrm{~d}$ & $84.07 a$ & $137.90 \mathrm{bcd}$ \\
\hline 1S X 0.60 & $12.15 b$ & $87.85 \mathrm{~b}$ & $0.65 a$ & $2.71 \mathrm{ab}$ & $8.63 \mathrm{~cd}$ & $4.11 \mathrm{~cd}$ & $84.11 \mathrm{a}$ & $107.88 \mathrm{~d}$ \\
\hline ON X 1.20 & $8.22 \mathrm{c}$ & $91.78 \mathrm{a}$ & $0.60 \mathrm{a}$ & $2.74 \mathrm{ab}$ & $8.45 \mathrm{~d}$ & $5.02 \mathrm{a}$ & $83.24 b$ & $158.42 \mathrm{ab}$ \\
\hline $0 \mathrm{~N} X 0.60$ & $8.55 c$ & $91.47 \mathrm{a}$ & $0.57 \mathrm{a}$ & $2.68 \mathrm{~b}$ & $10.81 \mathrm{a}$ & $4.82 \mathrm{ab}$ & 83.52ab & 178.93a \\
\hline
\end{tabular}

Dioscorea alata var. Agbodo

Dioscorea rotundata vars. Abuja, Iseosi and Oniyere

Means in any column followed by a common letter are not significantly different at $\mathrm{P}=0.05$ (Tukey's test)

Proximate analysis showed that ash and Crude fiber were not significantly different among the four varieties, as shown in (Table 2). Carbohydrate was lower in Oniyere, $83.38 \% \mathrm{dm}$, than in Agbodo and Iseosi which are $83.84 \% \mathrm{dm}$ and $84.09 \% \mathrm{dm}$ respectively. It was not significantly different from Abuja which is $83.80 \% \mathrm{dm}$ (Table 2). Crude Protein content of $4.92 \mathrm{dm}$ was higher in Oniyere than the other three varieties. Fat content of $0.63 \% \mathrm{dm}$ in Iseosi was significantly higher than in Abuja which is $0.55 \% \mathrm{dm}$. Fat content in Abuja $(0.55 \% \mathrm{dm})$, Agbodo $(0.62 \% \mathrm{dm})$, and Oniyere $0.59 \% \mathrm{dm}$ were not significantly different from one another. Dry matter content was higher significantly in Oniyere $91.70 \%$ than the other three varieties which were $86.10 \%$ (Abuja) $86.41 \%$ (Agbodo) and $87.22 \%$ (Iseosi) as shown in (Table 2). Moisture content of $8.38 \% \mathrm{dm}$ Oniyere was significantly lower than in Abuja 13.90\% dm), Agbodo $(13.59 \% \mathrm{dm})$ and Iseosi $(12.78 \% \mathrm{dm})$ (Table 2$)$. Phenol content was higher in Oniyere, $163.55 \mathrm{mg} / 100 \mathrm{gdm}$, than any of the other three varieties. The latter which had $135.26 \mathrm{mg} / 100 \mathrm{gdm}$ (Abuja), 133.87 $\mathrm{mg} / 100 \mathrm{dm}$ (Agbodo) and $122.89 \mathrm{mg} / 100 \mathrm{gdm}$ (Iseosi) are not significantly different from one another in phenol content (Table 2). There were no significant differences in any proximate component in terms of either $0.6 \mathrm{mll}^{-1}$ or $1.2 \mathrm{ml} \mathrm{l}^{-1}$ fertilizer treatment. In variety $\mathrm{x}$ fertilizer interactions phenol content of Oniyere $\mathrm{x}$ fertilizer $(0.60 \mathrm{ml}$ $\mathrm{l}^{-1}$ ) and Oniyere $\mathrm{x}$ fertilizer $\left(1.20 \mathrm{ml} \mathrm{l}^{-1}\right)$ were $178.93 \mathrm{mg} / 100 \mathrm{gdm}$ and $158.42 \mathrm{mg} / 100 \mathrm{gdm}$ respectively significantly higher than
Iseosi $\mathrm{x}$ fertilizer $\left(0.60 \mathrm{ml} \mathrm{l}^{-1}\right)$ which is $107.88 \% \mathrm{dm}$ and Abuja $\mathrm{x}$ fertilizer $\left(1.20 \mathrm{ml} \mathrm{l}^{-1}\right)$ which is $126.99 \mathrm{mg} / 100 \mathrm{gdm}$. Phenol content in the remaining five interactions were not significantly different from one another as shown also in (Table 2).

\section{Discussion}

Proximate and phenol content is compared only in the tubers fertilized with an 8- mineral component ( $\mathrm{Ca}, \mathrm{N}, \mathrm{MgO}, \mathrm{Mn}, \mathrm{Zn}$, $\mathrm{Cu}, \mathrm{Fe}, \mathrm{B}$ ) fertilizer namely Bounty. This is because resistance to the tuber rot pathogen $B$. Theobromae had been observed to correlate significantly with mineral uptake in white guinea yam (unpublished). However, both infection and weight loss were lower in the tubers from farmers plot (not Bounty fertilized) than in the bounty-fertilized tubers. Phenolics are often implicated in the resistance to microorganisms in plant species [5]. Phenol content was highest in variety Oniyere, but this did not reflect in a lower tuber infection compared to the other three varieties. But generally low infection of below $2 \%$ was recorded for each of the four varieties. Variety $\mathrm{x}$ fertilizer effects showed $0 \%$ weight loss in Agbodo x FPT and it was significantly lower than Oniyere x 0.60 fertilizer, Oniyere x 1.20 fertilizer, Abuja x 0.60 fertilizer and Abuja $\mathrm{x} 1.20$ fertilizer all of which had weight loss of over $2 \%$. Dioscorea alata is reported to have a longer storage of the fresh tubers than white guinea yam, [6]. D. rotundata. Lower moisture content has 
been reported to enhance/prolong shelf life in Dioscorea alata [7]. Moisture content in all four varieties in this study was over $8 \%$ and was lowest in the white Yam Oniyere. Low moisture commensurate to low infection or low weight loss may be varietal as the cited report recorded moisture levels of only $6 \%$ in the varieties of water yam studied [7]. Analysis of total phenolic compounds and minerals which are all implicated in reduction of infection/disease $[3,8]$ should explain varietal responses or response of tubers (storage organs) to pathogenic infection. However, mineral nutrition effects in reducing disease is evident as infection and weight loss in this study are only $97 \%$ and $67 \%$ respectively of that in a previous report, where Calcium carbonate reduced both infection and weight loss in three improved varieties of white and water yam (Dioscorea species) [9].

\section{References}

1. Onwueme IC (1978) The tropical tuber crops: Yams, Cassava, Sweet Potato and Cocoyams. John Wiley and Sons Ltd, Chichester, UK pp. 3-101.

2. Taiga A (2011) Comparative studies of the efficiency of some selected fungicidal aqueous plant extracts on yam tuber dry rot disease. Annals of Biological Research 2(2): 332-336.

ISSN: 2574-1241

DOI: 10.26717/BJSTR.2018.07.001478

Otusanya MO. Biomed J Sci \& Tech Res

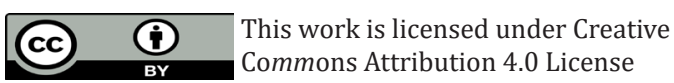

Submission Link: https://biomedres.us/submit-manuscript.php
3. Dordas C (2008) Role of nutrients in controlling plant diseases in sustainable agriculture: A review. Agronomy for Sustainable Development 28(1): 33-46.

4. Otusanya MO, Jeger MJ (1994) Infection of Yam Tubers by Aspergillus niger in relation to Isolate, Yam Species and Temperatures. International Biodeterioration and Biodegradation 33(4): 319-331.

5. Rees S, Harborne G (1985) The role of sesquiterpenes, lactones and phenolics in the chemical defence of the chicory plant. Phytochemistry 24(10): 2225-2231.

6. Baah FD, Maziya Dixon B, Ashiedu R, Oduro I, Ellis WO (2009) Nutritional and biochemical composition of Dioscorea alata (Dioscorea spp.) tubers. Journal of Food, Agriculture and Environment 7(2): 373-378.

7. Udensi EA, Oselebe HO, Iweala $\mathrm{OO}$ (2008) The investigation of chemical composition and functional properties of water yam (Dioscorea alata): Effect of varietal differences. Pakistan Journal of Nutrition 7(2): 342344 .

8. Dube HC (2014) Modern Plant Pathology (2nd edn.); Saraswati Purohit, Jodhpur pp.576.

9. Otusanya MO, Enikuomehin O, Popoola A, Adetunji M, Kehinde 0, et al. (2016) Effects of calcium fertilization on the susceptibility of Dioscorea species to the yam storage pathogens Aspergillus niger van Tiegh and Botryodiplodia theobromae pat. Journal of Plant Physiology and pathology 4(3).

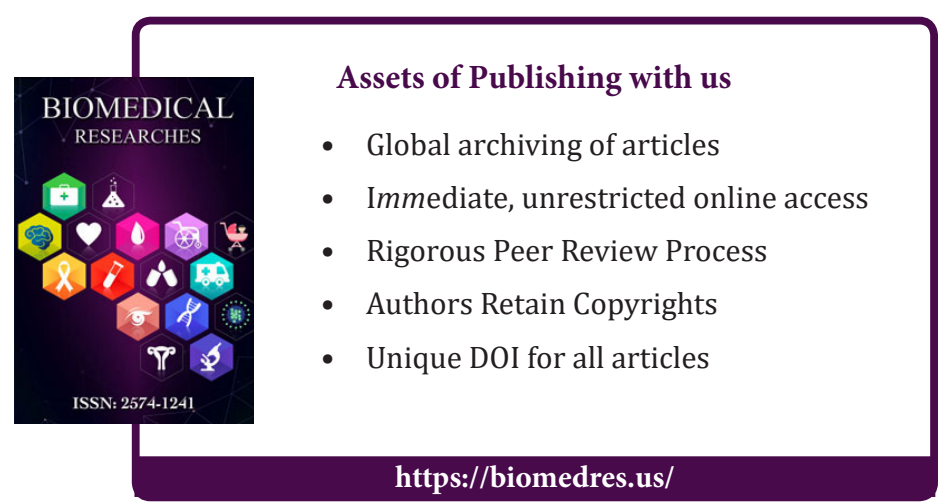

